\title{
FENOMENA NGANYARE KABIN PADA BULAN MUHARRAM DI DESA POJA KECAMATAN GAPURA KABUPATEN SUMENEP
}

\author{
Ahmad Rofiqi Emha \\ (Fakultas Syariah IAIN Madura Jl. Raya Panglegur km. 4 \\ Pamekasan, email: ahmadrofiqiemha@yahoo.com) \\ Azhar Amrullah Hafizh \\ (Fakultas Syariah IAIN Madura Jl. Raya Panglegur km.4 Pamekasan, \\ email:hafizh.forever@gmail.com) \\ Rusdiana Navlia \\ (Fakultas Tarbiyah IAIN Madura Jl. Raya Panglegur km.4 \\ Pamekasan,email: rusdiananavlia005@gmail.com)
}

\begin{abstract}
Abstrak:
Perkawinan merupakan sebuah akad sakral yang dianggap sebagai janji sekali seumur hidup. Pada perkembangannya, ada sebuah fenomena yang terjadi di dalam masyarakat Madura yang dilakukan dalam upaya untuk kembali merefresh janji suci tersebut terutama pada bulan Muharram, fenomena itu adalah Praktek Nganyar kabin. Praktek Nganyar kabin merupakan praktek mengulang akad perkawinan karena ada motif dan tujuan tertentu, yaitu untuk memperkokoh ikatan rumah tangga. Penelitian ini berusaha untuk mengeksplorasi pelaksanaan Fenomena Nganyar kabin pada Bulan Muharram di Desa Poja Kecamatan Gapura Kabupaten Sumenep, dan apa yang melatar belakangi masyarakat lebih memilih Bulan Muharram dalam melakukan Nganyar kabin, serta status hukum Nganyar kabin dan pelaksanaannya. Penelitian ini menggunakan pendekatan kualitatif, sedangkan jenis penelitiannya adalah fenomenologi. Penelitian ini menunjukkan bahwa dalam proses pelaksanaan nganyare kabin ada harapan bahwa pernikahan akan lebih bahagia dan barokah, sehingga dilaksanakan di bulan Muharram yang dianggap bulan keramat. (Marriage is a sacred contract that is considered a once-in-a-lifetime promise. In its development, there was a phenomenon that occurred in Madurese society which was carried out in an effort to refresh the sacred promise, especially in Muharram, the phenomenon was the Nganyar kabin practice. The Nganyar kabin practice is the practice of repeating
\end{abstract}


marriage contracts because there are certain motives and goals, namely to strengthen the bond of the household. This study explores the implementation of the Nganyar kabin phenomenon at Muharram Month in Poja Village, Gapura SubDistrict, Sumenep District, and what is behind the community prefers Moon Muharram in performing Nganyar kabin, as well as Nganyar kabin legal status and its implementation. This study uses a qualitative approach, while the type of research is phenomenology. This research shows that in the implementation process of Nganyar kabin, there is hope that the marriage will be happier and blessed, so that it will be held on the Muharram month which is considered a sacred month).

\section{Kata Kunci:}

Perkawinan, Nganyar kabin, Muharram, Sumenep.

\section{Pendahuluan}

Perkawinan merupakan sunnatullah yang umum dan berlaku pada semua makhluk-Nya, baik pada manusia, hewan, maupun tumbuh-tumbuhan. Ini adalah suatu cara yang dipilih oleh Allah sebagai jalan bagi makhluk-Nya untuk berkembang biak dan melestarikan hidupnya. Akan tetapi dalam konteks kemanusiaan perkawinan lebih dikenal dengan pernikahan dan itu mempunyai aturan tertentu dalam pelaksanaanya.

Dalam Undang Undang Perkawinan Bab 1 pasal 1 menjelaskan bahwa Perkawinan adalah ikatan lahir batin antara seorang pria dan seorang wanita sebagai suami istri dengan tujuan membentuk keluarga (rumah tangga) yang bahagia dan kekal berdasarkan ketuhanan yang Maha Esa. ${ }^{1}$

Menurut Abdurrahman Al-jaziry, perkawinan adalah suatu perjanjian suci antara seorang laki-laki dan seorang perempuan untuk membentuk keluarga bahagia. Definisi itu memperjelas pengertian bahwa perkawinan itu adalah perjanjian. Sebagai perjanjian, ia mengandung pengertian adanya kemauan bebas antara dua pihak yang saling berjanji berdasarkan prinsip suka sama suka dan dalam pengertian ini jauh sekali dari segala yang dapat di artikan sebagai

1Undang-Undang Perkawinan dan Kompilasi Hukum Islam (Bandung: Citra Umbara, 2016), 2. 
mengandung suuatu paksaan. Oleh karena itu, baik pihak laki-laki maupun pihak perempuan yang mengikat janji dalam perkawinan mempunyai kebebasan penuh untuk menyatakan, apakah mereka bersedia atau tidak. ${ }^{2}$

Muhammad Abu Zahrah dalam kitabnya Al-Ahwal AlSyakhshiyyah mendefinisikan nikah sebagai akad yang menimbulkan akibat hukum berupa halalnya melakukan persetubuhan antara lakilaki dengan perempuan, saling tolong menolong serta menimbulkan hak dan kewajiban diantara keduanya. ${ }^{3}$ Definisi di atas menjelaskan bahwasanya pernikahan tidak hanya terletak pada sebuah ikatan baru akan tetapi juga ada hubungan biologis yang dapat dilakukan setelah pernikahan hingga memberikan kesan bahwa perempuan adalah objek kenikmatan lelaki.

Istilah nganyar kabin merupakan istilah yang lumrah dikenal pada sebagian masyarakat Indonesia. Praktek nganyar kabin adalah tradisi yang sudah ada dan berkembang dalam kehidupan masyarakat, khususnya di Madura. Dalam tradisi masyarakat Indonesia, nganyar kabin dikenal dengan nyar-nganyar kabin (Madura) dan nganyare nikah (Jawa). Secara sederhana, praktek nganyar kabin bisa diartikan dengan mengulang akad perkawinan karena ada motif dan tujuan tertentu, yaitu untuk memperkokoh ikatan rumah tangga.

Dalam kitab fikih, nganyar kabin dikonsepsikan sebagai akad ulangan yang dilakukan oleh suami istri untuk memperindah (AtTajammul) dan berhati-hati (al-ikhtiyat). Dengan demikian, nganyar kabin adalah sebuah keputusan yang diambil oleh pasangan suami istri untuk melangsungkan akad kembali kerena disebabkan oleh alasan tertentu. ${ }^{4}$ Dari pemaparan definisi nganyar kabin sebagaian masyarakat Indonesia khususnya di wilayah Madura Desa Poja Kecamatan Gapura Kabupaten Sumenep, bahwa dalam pelaksanaannya, nganyar kabin selain dilaksanakan karena alasan tertentu juga dilaksanakan pada bulan Muharram, disebabkan kepercayaan masyarakat Desa Poja bahwa bulan Muharram

\footnotetext{
2 Beni Ahmad Saebani, Fiqh Munakahat 1 (Bandung: CV Pustaka Setia, 2013),. 19.

3 Amir Nuruddin dan Azhari Akmal Tarigan Hukum Perdata Islam di Indonesia(studi Kritis Perkembangan Hukum Islam dari Fikih, Undang-Undang Nomor 1/1974 sampai KHI), (Jakarta: Kencana, 2004), hlm. 39.

4 Syaiful Bahri. "Kontroversi Praktek Tajdid al-Nikah Dalam Perspektif Fiqih Klasik", Jurnal Al-Ahwal, Vol. 6, No. 2, (2013), hlm. 158.
} 
merupakan bulan yang penuh barokah sehingga masyarakat Desa Poja melakukan nganyar kabin di bulan Muharram untuk memperoleh barokah dari bulan tersebut.

Muharram adalah bulan di mana umat Islam mengawali tahun kalender Hijriah berdasarkan peredaran bulan. Muharram menjadi salah satu dari empat bulan suci yang terdapat dalam surat AtTaubah (09): 36

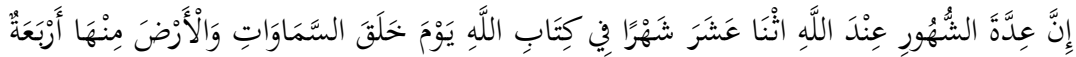

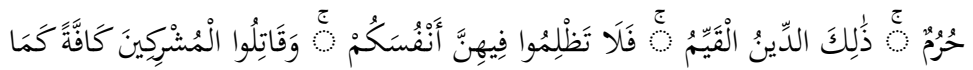

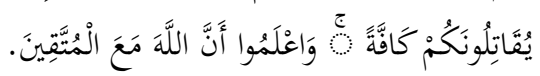

"Sesungguhnya jumlah bulan menurut Allah ialah dua belas bulan (sebagaimana) dalam ketetapan Allah pada waktu Dia menciptakan langit dan bumi, diantaranya ada empat bulan haram. Itulah (ketetapan) agama yang lurus, maka janganlah kamu menzhalimi dirimu dalam (bulan yang empat) itu, dan perangilah kaum musyrikin semuanya sebagaimana merekapun memerangi kamu semuanya. Dan ketahuilah bahwa Allah beserta orang-orang yang takwa.".5

Al-Qadhi Abu Ya'la mengatakan, "Dinamakan bulan haram karena dua makna, Pertama: pada bulan tersebut diharamkan berbagai pembunuhan atau peperangan. Orang-orang Jahiliyyah pun meyakini demikian. Kedua: pada bulan tersebut larangan untuk melakukan perbuatan haram lebih ditekankan dari pada bulan yang lainnya karena mulianya bulan tersebut. Demikian pula pada saat itu sangatlah baik untuk melakukan amalan ketaatan." Demikian pendapat Ibnul Jauzi ketika menafsirkan surat At Taubah ayat 36.

Ibnu 'Abbas mengatakan, "Allah mengkhususkan empat bulan tersebut sebagai bulan haram, dianggap sebagai bulan suci. Melakukan maksiat pada bulan tersebut dosanya akan lebih besar, dan amalan sholeh yang dilakukan akan menuai pahala yang lebih banyak."

Bulan Muharram betul-betul istimewa karena disebut syahrullah yaitu bulan Allah, dengan disandarkan pada lafazh Allah bulan ini menunjukkan keagungan dan keistimewaannya.

Al-Zamakhsyari, dinukil dari Faidh al-Qadir, mengatakan, "Bulan Muharram ini disebut syahrullah (bulan Allah), disandarkan

${ }^{5}$ Depertemen Agama RI, Mushafal-Qur'an Terjemah (Jakarta: al-Huda, 2002)., 78. 
pada lafazh jalalah 'Allah' untuk menunjukkan mulia dan agungnya bulan tersebut, sebagaimana pula kita menyebut 'Baitullah' (rumah Allah) atau 'Ahlullah' (keluarga Allah) ketika menyebut Quraisy. Penyandaran yang khusus di sini dan tidak kita temui pada bulanbulan lainnya, ini menunjukkan adanya keutamaan pada bulan tersebut. ${ }^{6}$

Penelitian ini menggunakan teori 'Urf sebagai salah satu dasar dalam menetapkan suatu hukum yang tidak ada nashnya secara eksplisit dalam Al-Qur'an maupun Al-Hadits. 'Urf oleh sebagian besar fuqaha menjadi metode dalam menetapkan suatu hukum, sementara oleh yang lainnya menjadi sumber hukum. ${ }^{7}$

Fenomena nganyar kabin memang sangat jarang dilakukan oleh masyarakat Madura, akan tetapi berbeda dengan salah satu desa di Kabupaten Sumenep tepatnya di Desa Poja Kecamatan Gapura, justru praktek nganyar kabin biasa dilakukan pada bulan muharram dengan beberapa alasan dan tujuan tertentu, diantaranya adalah ikhtiyat (berhati-hati), at-tajammul (memperindah), menjaga keharmonisan rumah tangga dan bahkan ada juga dengan alasan untuk memperbaiki ekonomi keluarga. Sehingga penelitian ini menjadi sangat menarik dan urgen untuk diangkat.

Dari sini timbul beberapa pertanyaan yaitu: Bagaimana pelaksanaan Fenomena Nganyar kabin pada Bulan Muharram di Desa Poja Kecamatan Gapura Kabupaten Sumenep ? Apa yang melatar belakangi masyarakat lebih memilih Bulan Muharram dalam melakukan Nganyar kabin di Desa Poja Kecamatan Gapura Kabupaten Sumenep ? Bagaimana status hukum Nganyar kabin dan pelaksanaannya pada bulan Muharram di Desa Poja Kecamatan Gapura Kabupaten Sumenep?

\section{Metode Penelitian}

Pendekatan yang digunakan dalam penelitian ini adalah pendekatan kualitatif. Dalam penelitian kualitatif ini, identitas dan peran informasi-informasi yang disampaikan menjadi hal-hal yang berharga sehingga peneliti harus memiliki tanggung jawab untuk memperlakukan identitas diri dan informasi yang disampaikan oleh informan. Identitas dan informasi tersebut dapat dibuka atau tertutup

${ }^{6}$ Ahmad Khairuddin, "Asyura: Antara Doktrin, Historis dan Antropologis Perspektif Dakwah Pencerahan.", Jurnal Al-Hiwar, Vol. 3, No.5 (Januari, 2015),. 2.

7 Jaih Mubarak, Modifikasi Hukum Islam : Studi tentang Qawl Qadim dan Qawl Jadid (Jakarta : Rajagrafindo Persada, tahun 2002),. 30. 
untuk khalayak, tegantung dari kesepakatan antara peneliti dan informan yang tertulis dalam formulir kesepakatan. Peneliti boleh membuka identitas selama informan sepakat dan peneliti juga harus menghargai keputusan apabila informan ingin identitasnya dilindungi.

Sedangkan jenis penelitiannya, peniliti menggunakan jenis fenomenologi. Dimana peneliti mempunyai keinginan untuk mengungkapkan fenomena yang sedang berkembang di lapangan dan menjadi objek yang mempunyai daya ketertarikan untuk dijadikan suatu penelitian. Jenis fenomenologi ini merupakan kebenaran sesuatu itu dapat diperoleh dengan cara menangkap fenomena atau gejala yang memancar dari objek yang diteliti. Maka yang dimaksud dengan Penelitian deskriptif fenomenologis adalah suatu jenis penelitian yang ditujukan untuk mendeskripsikan fenomena-fenomena yang ada baik fenomena ilmiah atau fenomena buatan manusia. ${ }^{8}$

Sebelum mengambil dan menganalisis data, maka pertama yang harus dilakukan oleh peneliti adalah mengetahui obyek penelitian dengan cara menentukan lokasi penelitian dimana peneliti akan melakukan penelitian.

Penelitian ini dilakukan di Desa Poja Kecamatan Gapura, lokasi ini dianggap tepat untuk dilakukan penelitian karena ditempat ini ditemukan sesuatu yang menarik untuk diteliti, yakni tentang Fenomena nganyar kabin yang dilaksanakan pada Bulan Muharram mengingat konsep dalam mendapatkan kekuatan hukum yang diatur dalam Undang-undang perkawinan adalah dengan Isbat Nikah bukan nganyar kabin. Walaupun dalam agama nganyar kabin itu diperbolehkan.

Sumber data utama dalam penelitian ini adalah pasangan suami istri yang ada di Desa Poja Kecamatan Gapura, mengingat mereka adalah pelaku dari masalah yang akan diteliti oleh peneliti, yakni mengenai tentang Fenomena nganyar kabin di Bulan Muharram. Dalam hal ini peneliti juga akan mendapatkan sumber data dari Kepala Desa Poja, Tokoh Agama di desa Poja, Kec. Gapura sebab mereka adalah masyarakat Desa Gapura yang banyak mengetahui tentang Fenomena nganyar kabin di Bulan Muharram.

\footnotetext{
8 Suharsimi Arikunto, Prosedur Penelitian: Suatu Pendekatan Praktik (Jakarta: Renika Cipta, 2006),. 14.
} 
Analisis data ini bertujuan untuk menyempitkan dan membatasi penemuan-penemuan sehingga menjadi suatu data yang teratur, tersusun dan lebih berarti. Seperti yang dikatakan oleh Moh. Kasiram bahwa tujuan utama dari analisis data ialah untuk meringkaskan data dalam bentuk yang mudah dipahami dan mudah ditafsirkan, sehingga hubungan antara problem penelitian dapat dipelajari dan diuji..$^{9}$ Yang dianalisis dalam penelitian ini adalah data yang telah terhimpun dalam transkip wawancara dokumentasi dan observasi. Adapun tahapan yang dilakukan dalam analisis data ini adalah Reduksi data, Display data, dan kesimpulan dan veririkasi data.

\section{Kajian Teoretik Nganyar Kabin}

\section{A. Pengertian Tajdid al-Nikah (Nganyar kabin)}

Hubungan Tajdid al- Nikah ialah berasal dari kata Tajdid dan Nikah yang mana Tajdid secara etimologi adalah bentuk masdar dari asal kata جَدَّدَ يُجَدِّد تَجْدِيدًا yang berarti Pembaharuan. ${ }^{10}$ Adapun yang dimaksud dengan pembahuran disini adalah memperbaharui.Dalam arti Tajdid juga mengandung arti lain yakni ialah pembaharuan dengan cara mengeinterpretasi ulang terhadap agama Islam sehingga ajaran itu dapat diterima dalam situasi modern. ${ }^{11}$

Sedangkan menurut istilah Tajdid ialah mempunyai dua makna yaitu, pertama, apabila dilihat dari segi sasarannya, dasarnya, landasan dan sumber yang tidak berubah-ubah, maka tajdid bermakna mengembalikan segala sesuatu kepada aslinya. Kedua, Tajdid bermakna modernisasi, apabila sasarannya mengenai hal-hal yang tidak mempunyai sandaran, dasar, landasan, dan sumber yang tidak berubah-ubah untuk disesuaikan dengan situasi dan kondisi serta ruang dan waktu. ${ }^{12}$

\section{B. Pengertian Bulan Muharram}

\footnotetext{
${ }_{9}^{9}$ Moh. Kasiram, Metodologi penelitian (Malang: UIN MALIKI Press, 2010), 120.

10 A.W. Munawwir, Kamus al-Munawwir Arab-Indonesia (Surabaya: Pustaka Progressif, 1997),. 345.

11 Abu Muhammad FH dan Zainuri Siroj, Kamus Istilah Agama Islam (KIAI), (Jakarta: Pt Albama, t.t), 302.

12 Abdul Manan, Reformasi Hukum Islam di Indonesia (Jakarta: Raja Grafindo Persada, 2006), 147.
} 
Bulan Muharram adalah salah satu dari empat bulan haram atau bulan yang dimuliakan Allah. Empat bulan tersebut adalah, Dzulqa'dah, Dzulhijjah, Muharram dan Rajab.

Kata Muharram artinya 'dilarang'. Sebelum datangnya ajaran Islam, bulan Muharram sudah dikenal sebagai bulan suci dan dimuliakan oleh masyarakat Jahiliyah. Pada bulan ini dilarang untuk melakukan hal-hal seperti peperangan dan bentuk persengketaan lainnya. Kemudian ketika Islam datang kemuliaan bulan haram ditetapkan dan dipertahankan sementara tradisi jahiliyah yang lain dihapuskan termasuk kesepakatan tidak berperang. ${ }^{13}$

C. Berbagai Tradisi dan Kepercayaan yang Berkembang Seputar Asyura.

Di samping banyaknya keutamaan Muharram, ada beberapa hal yang berkembangan di kalangan umat Islam menyangkut hari Asyura khususnya. Beberapa hal yang masih menjadi keyakinan di kalangan umat Islam adalah legenda bahwa pada hari' Asyura Nabi Adam diciptakan, pada hari 'Asyura Nabi Ibrahim dilahirkan, pada hari 'Asyura Allah Swt menerima tobat Nabi Ibrahim, pada hari 'Asyura Kiamat akan terjadi dan siapa yang mandi pada hari 'Asyura diyakini tidak akan mudah terkena penyakit. Hanya saja semua cerita tersebut tidak memiliki landasan dan dalil yang kuat dalam Islam. Begitu juga dengan keyakinan bahwa disunnahkan bagi mereka untuk menyiapkan makanan khusus untuk hari 'Asyura.

\section{Hasil Penelitian}

Berdasarkan data yang diperoleh dari hasil wawancara, observasi tersebut maka dapat ditemukan hasil temuan penelitian sebagai berikut:

Dalam temuan wawancara ini peneliti membagi menjadi dua bagian yaitu wawancara dengan suami istri yang melaksanakan nganyar kabin dan wawancara kepada tokoh masyarakat. Hasil wawancara adalah sebagai berikut:

A. Pelaksanaan Nganyar kabin Pada Bulan Muharrom Di Desa Poja Kecamatan Gapura Kabupaten Sumenep.

1. Peneliti menemukan bahwa tradisi nganyar kabin pada bulan Muharram diyakini oleh kalangan masyarakat desa poja

13 Bayan Dewan Syariah Pusat Partai Keadilan Sejahtera, Tentang Keutamaan Bulan Muharram, (Jakarta: t.p, t.t),. 1. 
untuk mempererat hubungan suami istri yang lebih harmonis, ingin mempunyai keturunan, supaya lebih berkah hubungannya agar tidak ada perselisihan lagi, dan menghormati warisan leluhur.

2. Proses pelaksanaan nganyar kabin sama halnya dengan pernikahan pada umumnya hanya tidak ada walimah, tidak ada rentetan acara lainnya, proses pelaksanaanya di dhelem (kediaman) kyai dan bukan dikantor KUA.

3. Bentuk praktik pelaksanaan nganyar kabin sama halnya dengan akad nikah sebelumnya, seperti ada wali ada dua orang saksi ijab qabul dan doa (amin pendek), dan tidak ada resepsi.

4. Ketika akan melaksanakan nganyar kabin pasangan suami istri siap untuk melaksanakan prosesi akad dengan harapan rumah tangga lebih harmonis dan berkah.

B. Latar belakang praktek Nganyar kabin pada bulan Muharrom di Desa Poja Kecamatan Gapura Kabupaten Sumenep.

1. Peneliti menemukan bahwa masyarakat yang melakukan nganyar kabin berdasarkan primbon, lebih hati-hati dikarenakan minimnya ilmu pengetahuan tentang kekeluargaan (mengatakan talak sebab emosi).

2. Peneliti menemukan bahwa motif atau alasan masyarakat untuk melaksanakan nganyar kabin pada bulan Muharram untuk ikhtiyat, keharmonisan rumah tangga, kesenjangan ekonomi, belum mempunyai ketururnan.

3. Masyarakat memilih bulan Muharram karena bulan Muharram merupakan bulan yang baik, bulan yang penuh dengan barokah bulan mulya dan bulan yang suci kemudian bulam Muharram dianggap sebagai bulan keramat karena terletak pada awal bulan yang diyakini seperti bayi baru lahir dan bulan Muharram dinilai istimewa tidak bermakna tathoyyur karena disebut syahrullah yaitu bulan Allah.

4. Dampak positif atau manfaat nganyar kabin yaitu hubungan rumah tangganya lebih harmonis, hubungan keluarganya lebih baik dari sebelumnya, bisa mempunyai keturunan dengan ridho Allah, untuk ikhtiyat (kehati-hatian) khawatir akad yang pertama rusak karena hal-hal yang tidak disengaja .

C. Status Hukum Nganyar kabin Perspektif Hukum Islam 
Dari Masalah nganyar kabin atau memperbaharui nikah dalam kajian fiqh ada dua pendapat ulama',

1. Ada yang membolehkan bahwasanya Nganyar kabin itu boleh dengan alasan tajammul dan ihtiyat. Karena akad nikah yang kedua tidak membatalkan atau memfasakh akad nikah yang pertama sebab dengan adanya akad nikah yang kedua bukan berarti adanya talak sehingga habisnya tanggung jawab atas nikah yang pertama.

2. Ada juga yang tidak membolehkan nganyar kabin jika dimaksudkan untuk membatalkan yang pertama karena menganggap pernikahan yang pertama kurang baik atau menganggap pernikahan yang telah berlangsung sekian lama itu dikhawatirkan pernah terucap thalaq dari lisan sang suami, maka menurut sebagian ulama' Syafi'iyah nikah yang pertama itu batal.

Dengan demikian status hukum tajdid nikah perspektif hukum Islam bahwasanya pengulangan akad atau memperbarui akad pada dasarnya bukanlah bentuk akad baru yang berbeda dengan akad yang pertama, ia hanya sebuah upaya untuk membuat kehidupan rumah tangga lebih indah dan harmonis.

Pada faktanya kasus yang terjadi di Desa Poja Kecamatan Gapura Kabupaten Sumenep pernikahan tersebut untuk memperbaharui akad, untuk berhati-hati (kehati-hatian) dalam akad pernikahan, atau juga dapat dikatakan untuk memperkuat pernikahan dapat disebut tajdid nikah dan hukumnya boleh. Hal ini terdapat pada kasus keraguan pasangan suami istri di Desa Poja.

\section{Penutup}

Proses pelaksanaan nganyareh kabin sama halnya dengan pernikahan pada umumnya hanya tidak ada walimah, tidak ada rentetan acara lainnya, proses pelaksanaanya di dhelem (kediaman) kyai dan bukan dikantor KUA. Latar belakang praktek nganyareh kabin bahwa masyarakat yang melakukan nganyareh kabin berdasarkan primbon, lebih hati-hati dikarenakan minimnya ilmu pengetahuan tentang kekeluargaan (mengatakan talak sebab emosi). Motif atau alasan masyarakat untuk melaksanakan nganyareh kabin pada bulan muharram untuk ikhtiyat, keharmonisan rumah tangga, kesenjangan ekonomi, belum mempunyai ketururnan. Hukum dari 
Nganyar kabin adalah Pertama boleh dengan alasan tajammul dan ihtiyat. Kedua, tidak membolehkan jika dimaksudkan untuk membatalkan yang pertama karena menganggap pernikahan yang pertama kurang baik atau menganggap pernikahan yang telah berlangsung sekian lama itu dikhawatirkan pernah terucap thalaq dari lisan sang suami.

\section{Daftar Pustaka}

Arikunto, Suharsimi. Prosedur Penelitian: Suatu Pendekatan Praktik. Jakarta: Renika Cipta, 2006.

Bahri, Syaiful. "Kontroversi Praktek Tajdid al-Nikah Dalam Perspektif Fiqih Klasik". Jurnal Al-Ahwal, Volume 6, Nomer 2, (2013).

Kasiram, Moh. Metodologi penelitian. Malang: UIN MALIKI Press, 2010.

Khairuddin, Ahmad. "Asyura: Antara Doktrin, Historis dan Antropologis Perspektif Dakwah Pencerahan.". Jurnal AlHiwar, Volume 3, Nomer 5, (Januari, 2015).

Manan, Abdul. Reformasi Hukum Islam di Indonesia. Jakarta: Raja Grafindo Persada, 2006.

Mubarak, Jaih. Modifikasi Hukum Islam : Studi tentang Qawl Qadim dan Qawl Jadid. Jakarta : Rajagrafindo Persada, tahun 2002.

Munawwir, A.W. Kamus al-Munawwir Arab-Indonesia. Surabaya: Pustaka Progressif, 1997.

RI, Depertemen Agama. Mushaf al-Qur'an Terjemah. Jakarta: al-Huda, 2002.

Saebani, Beni Ahmad. Fiqh Munakahat 1. Bandung: CV Pustaka Setia, 2013.

Sejahtera, Bayan Dewan Syariah Pusat Partai Keadilan. Tentang Keutamaan Bulan Muharram. Jakarta: t.p, t.t.

Siroj, Abu Muhammad FH dan Zainuri. Kamus Istilah Agama Islam (KIAI). Jakarta: Pt Albama, t.t.

Tarigan, Amir Nuruddin dan Azhari Akmal. Hukum Perdata Islam di Indonesia(studi Kritis Perkembangan Hukum Islam dari Fikih, Undang-Undang Nomor 1/1974 sampai KHI). Jakarta: Kencana, 2004. 
Ahmad Rofiqi Emha

Undang-Undang Perkawinan dan Kompilasi Hukum Islam. Bandung: Citra Umbara, 2016. 